\title{
Article \\ Novel Insights in the Leadership in Business and Economics: A Post-Coronavirus Update
}

\author{
Wadim Strielkowski ${ }^{1,2}, * \mathbb{D}$, Irina Firsova ${ }^{3}$, Svetlana Azarova ${ }^{3}$ and Irina Shatskaya ${ }^{4}$ \\ 1 Energy Economics \& Policy Research Group, Cambridge Institute for Advanced Studies, King Str. 23, \\ Cambridge CB1 1AH, UK \\ 2 Department of Trade and Finance, Faculty of Economics and Management, \\ Czech University of Life Sciences Prague, Kamýcká 129, 16500 Prague, Czech Republic \\ 3 Department of Logistics and Marketing, Faculty of Economics and Business, Financial University under the \\ Government of the Russian Federation, Leningradskiy Prospekt 55, 125993 Moscow, Russia; \\ ifirsova@fa.ru (I.F.); sazarova@fa.ru (S.A.) \\ 4 Department of Economics, Institute of Management Technologies, MIREA-Russian Technological University, \\ Vernadskogo Prospekt 78, 119454 Moscow, Russia; shatskaya@mirea.ru \\ * Correspondence: strielkowski@pef.czu.cz or strielkowski@cantab.net
}

Citation: Strielkowski, Wadim, Irina Firsova, Svetlana Azarova, and Irina Shatskaya. 2022. Novel Insights in the Leadership in Business and Economics: A Post-Coronavirus Update. Economies 10: 48. https://doi.org/10.3390/ economies10020048

Academic Editor: Ralf Fendel

Received: 18 January 2022

Accepted: 10 February 2022

Published: 15 February 2022

Publisher's Note: MDPI stays neutral with regard to jurisdictional claims in published maps and institutional affiliations.

Copyright: (C) 2022 by the authors. Licensee MDPI, Basel, Switzerland. This article is an open access article distributed under the terms and conditions of the Creative Commons Attribution (CC BY) license (https:// creativecommons.org/licenses/by/ $4.0 /)$.

\begin{abstract}
Our world is evolving at an incredibly enormous speed and what was impossible three years ago is now a reality. The concept of leadership and leaders has also undergone profound transformations. Moreover, the recent COVID-19 pandemic caused a digital surge in the ways economic life, business, or education are perceived or conducted. The pandemic proved that small and large businesses, industries, and the whole economies can be suddenly upended by massive technological shifts. Hence, there is a need for a theoretical research update in leadership in business and economics that would bring new insights into this topic and define its place within the context of Sustainable Development Goals (SDGs). Our paper presents the novel insights for the leaders and the leadership concept in business and economics from various approaches and angles of view in the light of the COVID-19 pandemic with a focus on sustainable leadership and organizational resilience. It aims at outlying the theoretical background of leadership in business and economics after the pandemic and bringing up interesting and recent leadership case studies from all around of the world. Moreover, this paper aims as sharing the valuable insights into what it means to be a sustainable leader in business and economics, why leaders are needed, and how to become one. The main criteria of this research and its instrumentation include both the theoretical discussion based on the literature review and analysis and the empirical analysis that supports these theoretical provisions. The paper features an empirical model that assesses how business and economic leaders are searching for new ways of work and personal development during and after the COVID-19 pandemic using the own data from the 400 respondents collected in the Czech Republic and Russia. We found that the pandemic enhanced the emotional creativity of business and economic leaders and made them to invest and engage more into using new digital technologies and fundamentally altering the old ways of managing and governing their respective companies and institutions. Our results might provide valuable food for thought both for academics working on various angles of leadership, as well as for entrepreneurs and businesspeople who want to receive recent updates on the topic of leadership to use them in their daily work.
\end{abstract}

Keywords: leadership; business and economics; COVID-19 pandemic; digital revolution; sustainable leadership; organization resilience

JEL Classification: L10; M10; M15; O31 


\section{Introduction}

As the third year of the COVID-19 pandemic is starting, it might be the right time to conduct a concise post-coronavirus update by presenting some novel insights in the leadership in business and economics. The spread of the COVID-19 virus, followed by isolation measures and changes in economic behavior, has seriously impacted businesses and economics of the early 2020s (Sigala 2020; D'Adamo and Rosa 2020; Strielkowski et al. 2021; Ibn-Mohammed et al. 2021; or Czech et al. 2021). The outbreak of the COVID-19 pandemic has forced many businesses to close, resulting in unprecedented trade disruption in most industrial sectors (Xu et al. 2020; Yu et al. 2020). The current epidemic is having serious economic implications around the world, and it does not look like any country will remain unscathed. This is important not only for the rapid recovery of the economy from the COVID-19 crisis, but also for the prevention and management of such disasters in the future. According to Obermeier (2021) and Lenzen et al. (2020), global economic integration is essential to address the impact of the coronavirus pandemic. While business opportunities are being supported to tackle the COVID-19 pandemic, there are still limitations to mobilizing ongoing developments (Ansell et al. 2021; Wilson 2020; Goniewicz et al. 2020). Even though there are some accounts that the current omicron variant would become the end of the pandemic, we have to operate with what we have and carefully look into the future.

In this paper, we focus on the sustainable leadership, thence it appears necessary to discuss the sustainable leadership theories and organizational resilience, especially with regard to the recent pandemic and its impacts.

According to Hallinger and Suriyankietkaew (2018), sustainable leadership emerges as a new domain of study within the field of management as far as achieving sustainable development and growth in organizations and societies calls for leadership to provide clear visions, directions, and new goals for motivating people. What is crucial here is a focus on the long-run, balanced outcomes, ethical behavior, and corporate social responsibility (Avery and Bergsteiner 2011; Kantabutra 2014; Suriyankietkaew 2019; Iqbal et al. 2020).

With regard to that, Ketprapakorn (2019) or Kantabutra and Ketprapakorn (2020) provided a comprehensive review of the corporate sustainability showing that Asian companies tend to adopt the leadership practices of long-term focus, development of the internal leadership, cohesive corporate culture, innovation, social, and environmental responsibility, as well as ethical behavior which might be inspired but not entirely copied from their Western counterparts. This is in accord with Wilson (2003) view of the corporate sustainability represented by a corporate management paradigm that acknowledges the need for growth and profitability but puts more emphasis on the triple bottom line results and the public reporting on them.

The recent experience demonstrated that it is possible to deliver both sustainability and business performance, demonstrating that success in one area does not have to come at the expense of another (Fernando et al. 2019; Ketprapakorn and Kantabutra 2019a; or Yong et al. 2020). Among the challenges to be overcome are the values and practices ingrained in the organization that can be disrupted by sustainability strategies, and the progress of sustainability leaders will depend on taking certain internal measures, such as providing managers and employees with compelling information and strategic goals, creating incentives to integrate sustainability into daily practice, empowering people across the organization, and offering opportunities to learn about sustainability and its place in a business context (Hall 2019; Obrenovic et al. 2020; Shahzad et al. 2021). Nowadays, sustainable leadership aims for dramatic change and requires long-term decision-making required to encourage systemic innovations aimed at increasing customer value, developing a skilled, loyal, and dedicated workforce, offering quality products, services, and solutions, participating in ethical behavior and decision-making, and setting ethical values and standards throughout the organization (Domínguez-Escrig et al. 2019; Ketprapakorn and Kantabutra 2019b; Sachs et al. 2019; Hallinger 2020). Hence, sustainable performance depends on the efforts of many motivated and talented leadership members who are ready 
and willing to contribute to the well-being and development of the organization (Stahl et al. 2020). Because organizational learning is a dynamic skill and a source of sustainable competitive advantage, organizations can use sustainable leadership as a resource to improve it (Arsawan et al. 2020).

While doing the literature review on organizational resilience, we also need to mention the resilient organizations resilience benchmark tools for assessing organizational resilience. To improve return on investment and enhance resilience, every organization depends on its management's ability to strengthen, organize, and reallocate resources to use them more effectively. Success and survival in this uncertain environment require organizations to be resilient which is not about responding to a one-time crisis (Brown et al. 2017; Ruiz-Martin et al. 2018). Increasing resilience in times of uncertainty does not magically happen. The flexibility of the capability and behavior-based system allows organizations to select the goals and strategies they perceive as the most important and relevant to their organization in order to focus on improvement (Lee et al. 2013). The organizational resilience capacity assessment tool is a voluntary capability and behavior assessment system designed to allow organizations to assess their progress against a set of standardized goals and measures of assessment used by the most resilient organizations (Brown et al. 2019). Using the resilience measurement tool, individual organizations can see how their resilience compares to other organizations and how their departments or business units, sites, or locations compare to each other. Individual organizations can also use this tool to internally test their own resilience, allowing them to bridge knowledge gaps between offices, departments, and business units or organizational units (Stevenson et al. 2018). Thence, the resilience measurement tools allow to effectively analyze organizational resilience by industry using employee perceptions to measure the resilience of organizations.

During the recent COVID-19 pandemic and other "black swan-type" events that may have serious long-term consequences (Ahmad et al. 2021), in-depth understanding of business risks can help organizations make the right plans. The assessment provides policymakers with some early guidance on customizing COVID-19 business support packages, and points to new directions for data and research work needed to develop policies to respond to the current pandemic and future crises.

However, one can also see the COVID-19 pandemic as a product of human activities, mainly as a side effect (or a negative externality) of the ongoing industrial progress that goes hand in hand with the massive environmental pollution that leads to global warming and climate change. As a result of these processes, natural habitat of many wild species becomes exposed and animals encounter humans transferring many dangerous diseases to them. Figure 1 that follows offers a graphical scheme of the COVID-19 pandemic from the environmental pollution to the climate change and then through the inter-species encounters to the global epidemics and pandemics.

Essentially, an analysis of the impact of COVID-19 on the global economy can reveal that the economic conditions are influenced by various elements. The COVID-19 crisis could impact future productivity through its impact on business dynamics. Our findings highlight that business dynamics in 2020 were very different from those in the years prior to COVID-19 or during the 2008/2009 global crisis, and there is cause for concern. Exit of companies with more than one person did not change much (0.8\%) from 2019 to 2020 (Lemieux et al. 2020; Verick et al. 2021). This is different from what we saw during the global crisis. Interestingly, while the expectations and business plans of multinationals have been negatively affected by the COVID-19 pandemic, their confidence in businesses has increased owing to strong nationwide policy measures in host countries in the first quarter of 2020 (Ulak 2020). Using data from the first quarter of 2007 to the fourth quarter of 2021, we explored how business dynamics changed during the COVID-19 pandemic, and how they differ between different company sizes, industries, and other economic crises such as global crises. Some authors also highlight a number of negative aspects of the pandemic that could affect consumer behavior. For example, Pan and Zhang (2020) or Irawanto et al. (2021) argue that the COVID-19 pandemic is changing the way people live around 
the world, affecting their social, economic, and environmental context. Furthermore, it can be shown that the COVID-19 pandemic has had a dramatic impact on the political, environmental, and economic aspect of human life, on which psychological development and the so-called "organizational resilience" depend (Keshky et al. 2020; Jakovljevic et al. 2020; Kantabutra and Ketprapakorn 2021). The rapid global spread of COVID-19 has quickly overshadowed other recent outbreaks in both scale and magnitude.

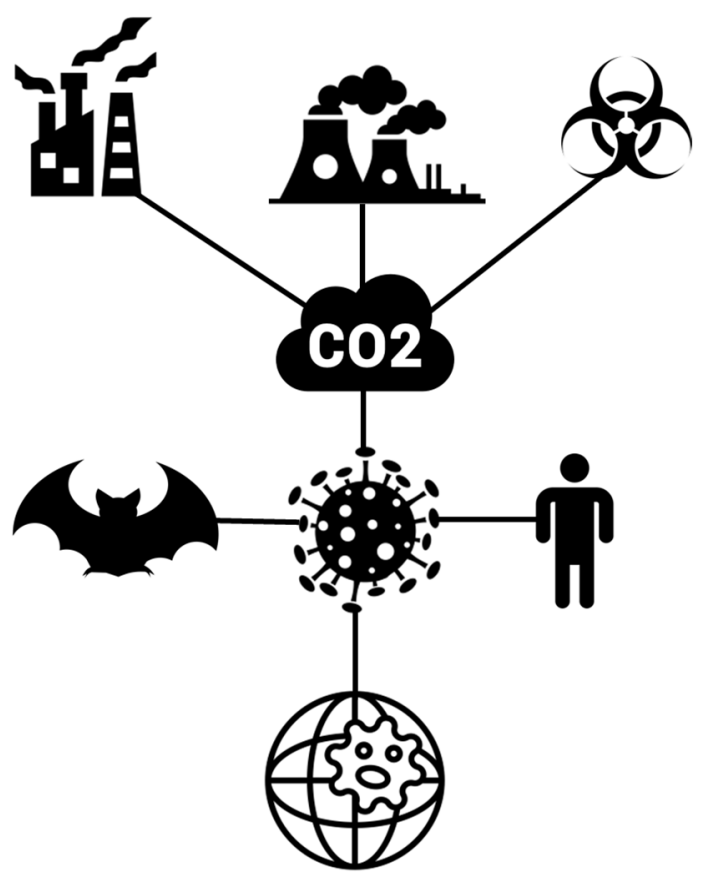

Figure 1. Origins and causes and of the COVID-19 pandemic. Source: own results.

In general terms, organizations and societies that can successfully meet and adapt to the challenges such as the COVID-19 pandemic are, by definition, resilient (Linnenluecke et al. 2012; Duit 2016; Roostaie et al. 2019; Duchek 2020). However, at some level, some sectors and organizations have shown resilience with better forecasting and surviving which could lead to a faster recovery. However, there are many organizations that have so far been resilient enough to be less affected by the pandemic, and many organizations are recovering faster than others even after they have been hit. As a result, organizations have begun prioritizing sustainability by allocating adequate budgets, resources, and time to ensure customer service continuity where applicable.

In addition to the death toll and the devastation of millions of lives, the economic damage is already significant and far-reaching. The global COVID-19 pandemic has forever changed our experience-customers, employees, citizens, people-and as a result, our attitudes and behavior are changing. Our baseline analysis of the pandemic this week explores a possible new era of global prosperity, with strong economic growth and skyrocketing health innovation (Fink 2020; Kirk and Rifkin 2020; Jiang and Stylos 2021).

Speaking about the theoretical significance and novelty of this paper, we concentrated on the novel insights into the post-pandemic economic and business landscape providing new perspectives on digital transformation, the future of work, transparency, and sustainability in the light of sustainable leadership and organizational resilience. In addition, we are demonstrating the effects of the change brought about by the COVID-19 pandemic and their implications for the emotional creativity (novelty, preparedness, effectiveness, and authenticity) and the way it is linked to the motivations of engaging into the new ways of learning and embracing the online technologies using our own unique sample of respondents from the Czech Republic and Russia, two countries that are distinguished by many similarities but also yield quite a number of differences. 
Our paper studies the following research question: what are the novel insights and outcomes for the leadership and leaders in business and economics stemming from the COVID-19 pandemic, both positive and negative, that can be identified using both the theoretical grounds and the empirical analysis? The paper is structured as follows: Section 2 discusses the theoretical framework focusing on the implications stemming from the COVID-19 on the digital transformation in business and economics. Section 3 contemplates over the lessons learnt from COVID-19 for risk management and organizational resilience. Section 4 discusses the issues of post-pandemic leadership and business in the light of the United Nations Sustainable Development Goals. Section 5 presents an empirical model that measures the adaptation processes of the business companies to the COVID-19 pandemic in the Czech Republic and Russia. Finally, Section 6 sums up the main findings of the paper and provides conclusions and policy implications.

\section{COVID-19 and the Digital Transformation}

In spite of all grim consequences and adverse effects it had on the healthcare, economy and social life, the recent pandemic has also caused some positive and long-lasting effects such as, for example, the digital transformation in business, economics, and, most importantly, education (Mhlanga and Moloi 2020; Korneeva et al. 2021; Bennett and McWhorter 2021). In the course of the COVID-19 pandemic, some key themes, such as, for example, the inequality and digital divide have worsened (Watts 2020; Azubuike et al. 2021).

During a pandemic, the need for alternative assessment and assessment methods and the necessary shift toward formative assessment through both synchronous and asynchronous means, and the use of online surveillance services as a means of combating deception and academic dishonesty are crucial (Jankowski 2020; Mpungose 2020; Savka 2021). It is also important to assess the teacher feedback and student satisfaction with online distance learning during isolation. The sudden shift to online learning during the COVID-19 pandemic is thought to be asocial phenomenon related to culture, technology, and human behavior, where multiple perspectives must be taken into account (Mukhtar et al. 2020; Moawad 2020). These topics reveal the many areas in which information security research can be focused on, in relation to the impact on technology. Internet access and the digital divide Information technology, and in particular the Internet, will remain at the center of a post-pandemic scenario in which innovation drives wider use. Some of the behaviors formed during the crisis, including the widespread adoption of digital technology, will survive the pandemic even after lifting restrictions on doing business (Shaw et al. 2020; Donthu and Gustafsson 2020). In order to remain competitive, organizations must respond to these changes in behavior and meet emerging customer needs. Examining the business impact of these changes can help people understand how organizations embrace their digital transformation and which parts of these changes are likely to continue (Mandych and Bykova 2021). However, the technology addiction fueled by the pandemic has forced people to keep a close eye on their technology investments and how they compare to what they need to run a digital business effectively. Current events have accelerated the development of the paradigm, as evidenced by the marked shift in spending toward digital business, and this is just the beginning. The pandemic is a reality check for companies that have been reluctant to embrace digital transformation and are now, unfortunately, not ready (Iivari et al. 2020; Gabryelczyk 2020). Moreover, the COVID-19 pandemic has led to an inevitable spike in digital use due to social distancing rules and nationwide restrictions (Pandey and Pal 2020). Furthermore, the COVID-19 pandemic has accelerated the digital transformation of more than a half of the businesses and organizations. Our research provides executives with key insights into the post-pandemic business landscape, providing new perspectives on digital transformation, the future of work, transparency and sustainability. Together, they provide guidance for proactive leaders who understand that the old way of working is a thing of the past. Digital transformation technologies such as cloud, Internet of Things (IoT), blockchain (BC), artificial intelligence (AI), and machine learning $(\mathrm{ML})$ constitute most of the technologies used by organizations in their transforma- 
tion efforts. However, simply leveraging digital technology is not the same as creating an autonomous and digitized supply chain, it also requires supply chain technologies linked through planning, procurement, manufacturing, and logistics that operate outside the four walls of an organization. Ultimately, digital and autonomous technologies will help make the work of people easier and the supply chain more efficient and streamlined. Many sources report that more than a half of the CEOs say that the pandemic has increased the strategic importance of their supply chains (De Sousa Jabbour et al. 2020; Gereffi 2020).

However, the speed at which managers said their companies have responded to the range of COVID-19-related changes is significant, even faster than their enterprisewide digitization. More than a half say COVID-19 has adapted their approach to change management and accelerated process automation, with a similar number acknowledging the move to more cloud-based business operations (Baptista et al. 2020). The COVID-19 pandemic has accelerated digital transformation in the majority of organizations, and most of them declare they were able to implement initiatives that had previously met resistance (Cone et al. 2021). The transformation is also accelerating in most organizations. More than three quarters of executives expect the change in customer behavior to continue after COVID-19, replacing personal contact with more online shopping and customer service interactions (Zgórska et al. 2021). In general, many executives expect customer behavior changes to continue following COVID-19 (Kim 2020). Before the pandemic, nearly half of companies said they viewed technology as a cost-cutting tool as one of their top three digital priorities (Bieck and Marshall 2020; Bennett and Mayouf 2021). Prior to the pandemic, more than half of companies believed that lack of priority was the main reason digital transformation and opportunity was not being applied (Priyono et al. 2020; Lee and Lee 2021). In just a few months, the COVID-19 crisis has brought about years of change in the way companies do business across all sectors and regions (Sheth 2020). Nowhere else has there been such unprecedented and unexpected growth as in the digital and e-commerce sectors, which surged during the COVID-19 crisis (Dannenberg et al. 2020; Kamal 2020). Due to the slowdown in economic activity, COVID-19 has led to a surge in e-commerce and an acceleration in digital transformation. As blocks become the new normal, businesses and consumers are increasingly digitalizing by supplying and buying more goods and services online, increasing the share of e-commerce in global retail from 14\% in 2019 to about 17\% in 2020 (Gu et al. 2021). The pandemic has helped accelerate digital transformation and created an environment that will continue to drive innovation and technology adoption in the future. The number of organizations resting on existing digital laurels may be fewer than those investing in adapting their digital capabilities for a post-coronavirus future-a future that is very different from the pre-pandemic world. COVID-19 has left the world in isolation by necessity. The COVID-19 pandemic has made digital platforms the only means by which people can maintain a social-emotional connection (Kanekar and Sharma 2020). As the spread of COVID-19 interferes with work, school, and even doctor visits across the country, most people worldwide are turning to digital means to stay connected and track information about the outbreak. For example, in the United States, amid this growing addiction, about nine in ten adults (93\%) say serious Internet or mobile disruption during an outbreak will be a problem in their daily lives, including $49 \%$ who expect power outages to be a big problem and $28 \%$ think it will be a moderately big problem (Anderson and Vogels 2020). Since digital communication has increased many-folds during the pandemic, these negative aspects of digital interactions can only intensify during social distancing. This analysis focuses on the role of digital technology in people's daily lives during the epidemic.

In general, there are several possible scenarios for this wave of information technology use during and after the pandemic. The assessment of these effects suggests that digital transformation has already occurred before the outbreak of the pandemic and that it will take shape due to the impact of the blockades. The idea of a turning point for technology adoption or digital disruption is not new, but some recent data show that the COVID-19 
crisis truly represents a historic turning point and that further changes will be required as the economic and humanitarian situation evolves.

In addition, our analysis would be incomplete without the description and the brief analysis of Industry 5.0 which is also changing leadership dimensions and models by providing new insights in the leadership in business and economics, especially in the light of the post-pandemic recovery (Aslam et al. 2020; Cillo et al. 2021). As the Fourth Industrial Revolution changes the future of work, companies must prepare their employees for the new world that awaits them. Preparing for Industry 5.0 is irrelevant, but there are many forces lining up to force companies to embrace the core principles of human centralization, resilience, and sustainability (Cobbinah et al. 2020). This new wave of technology and innovation offers companies the opportunity not only to make radical changes in productivity and efficiency, but also to capture strategic business value by creating a competitive advantage in the way they manage the entire value chain (Culot et al. 2019). As a result of this perfect storm of technology, the Fourth Industrial Revolution is paving way for transformational changes in the way we live and sweeping changes in almost every sector of business. The working interaction between humans and robots is heralding the next industrial revolution and fueling Industry 5.0 era (Glavič 2021). Instead of competing with robots for jobs, as feared by the advent of Industry 4.0, humans are expected to cooperate with them. Like Industry 4.0, which focused on the use of artificial intelligence (AI), big data, and the Internet of Things (IoT), Industry 5.0 embodies these systems and includes more advanced human intelligence (Rao and Prasad 2018; Olsen and Tomlin 2020). In short, Industry 5.0 adds personality to the two pillars of Industry 4.0: automation and efficiency (and both aspects proved to be crucial in the times of the COVID-19 pandemic). As machines in the workplace become smarter and more connected, Industry 5.0 seeks to combine the power of cognitive computing with human intelligence and ingenuity in collaborative operations (Javaid et al. 2021). The combination of human and machine will combine the potential precision of full automation with the critical and cognitive skills of business leaders. This can be achieved through the close cooperation of workers and machines, the application of Industry 5.0 technologies and the development of artificial intelligence. Since the use cases for Industry 5.0 are still relatively in their infancy, manufacturers must proactively develop human-mechanical worker integration strategies to maximize the unique benefits that can be gained as the movement evolves (Cao et al. 2021). The question is not whether a manufacturer can benefit from having its employees work alongside robots, but how it can make the most of new technologies to achieve optimal results from human-machine interaction. While many manufacturers are still busy developing ways to combine new technologies to increase efficiency and productivity, the next phase of industrialization is already here. Industry 5.0 and the Fifth Industrial Revolution could usher in a new socio-economic era that bridges the gap between "high" and "low", creating endless opportunities for humanity and making our planet a better place. Automation, smart factory, and digital transformation which proved to be very helpful and unexpandable during the last two years of the pandemic will become the successors of the digital economy and would impact the leadership style and leaders in business and economics after the dust after the pandemic settles.

\section{Lessons from COVID-19 for Risk Management and Organizational Resilience}

Up to this point, an important question emerges: what lessons for leaders and leadership in business and economics have we learnt from COVID-19 with respect to the risk management and organizational resilience? It becomes clear that each feature has not only helped business, social, and political leaders overcome the COVID-19 crisis, but now also points the way towards a more flexible operating model that can be more resilient in the next business as usual (Zhong et al. 2021). The pandemic was an unexpected event but it helped many business and economic leaders to set up their priorities. In addition, it helped businesses and organizations to perform a drill of what needs to be done if worse turbulences in economics, climate change, or geopolitics might emerge. 
A systematic approach based on resilience can probably be proposed to prepare the social and economic system for future shocks. Although this approach has many benefits, the COVID-19 crisis has also shown that it also reduces the organizational resilience of critical systems to shocks and allows interruptions to spread from one system to another (Hynes et al. 2020; Golan et al. 2020). On the contrary, the emphasis on increasing the organizational resilience of the international economic system is a necessary evolution in the post-COVID-19 world, where the system is designed to facilitate recovery and adaptation from interruptions (Sharma et al. 2021). There is a need to integrate risk-based approaches with resilience-based approaches to manage outbreaks as well as other systemic threats. Organizational resilience recognizes that massive disruptions can and will occur in the future, climate disruptions can exacerbate other shocks such as pandemics, and it is essential that major systems are resilient and adaptable to ensure their survival and even take advantage of newer emerging opportunities after crises to improve the system through broader systemic change (Linnenluecke 2017; Gorjian Khanzad and Gooyabadi 2021; Kontogiannis 2021). The pandemic offers an opportunity to better deal with other emergencies such as climate change. Conversely, digital resilience can be defined as the ability of an enterprise to not only recover core business opportunities, but also take advantage of a changed environment to recover even better than before (Sanchis et al. 2020; Bai et al. 2021). Unsurprisingly, agile working methods have allowed organizations to be more resilient to crises like the COVID-19 pandemic. To move toward an agile operating model, organizations need to reflect on what they have learned during the crisis and know what practices need to be supported. Lessons learned from these examples highlight that organizations should maintain the fast decision cycles they have implemented during the COVID-19 crisis, but in the long term. Organizations that want to maintain the benefits they enjoyed during the COVID-19 crisis, such as faster decision-making and clarity of purpose, must make that choice now. A digital resilient organization must have advanced approaches to data privacy and security, or its reputation could be compromised. Perhaps the biggest risk to a company's brand and reputation is the way customer data are handled. This is often overlooked in traditional approaches to business resilience, which typically focus on protecting individual business functions or activities on a partial basis. It is also often overlooked by standard IT risk management and disaster recovery practices that protect specific IT assets and resources. These setbacks also indicate where efforts can be directed to reduce overall vulnerability and build resilience, including the risks of climate change (Kure et al. 2018; Casola et al. 2020).

The recent pandemic has highlighted the importance of effective cross-border cooperation, coordination, and risk sharing. In addition, attention should be also paid to further developing work related to third-party risk management and outsourcing, and will formulate expectations for financial authorities to use when monitoring financial institutions that rely on key service providers. COVID-19 emphasizes the importance of effectively managing operational risks before shocks occur. All of those are important lessons learned from the COVID-19 response to disaster risk management through a systematic assessment of COVID-19, which provides opportunities for the world to resist multiple risks. Lessons learned from the COVID-19 pandemic have opened the door to more research and actions to ensure that cities are inclusive of climate change. It also raised key issues for changing the perception of organizational resilience, highlighting key lessons learned to enable communities to withstand impending extreme shocks and economic, environmental, and social impacts. The coronavirus outbreak highlighted our limited resilience from healthcare to retail, transportation to food and medical networks. Moreover, the pandemic provided climate risk managers and researchers with specific lessons about the systematic behavior of social care, public health, and interconnected livelihoods in long-term crises, and the transfer of risks through the procurement chain (Sarkis 2021). If climate change risks have an impact, this will affect vulnerability and response capacity (Lambert et al. 2020). Both infection routes are active during the COVID-19 pandemic and can provide lessons for studying climate change risks. 


\section{Post-Pandemic Leadership and Business in the Light of SDGs}

Few words should be said about the Sustainable Development Goals (SDGs) within the context of the subject of this research. The SDGs (also known as global goals) aim to eradicate poverty, hunger, and inequality, address climate and environmental changes, improve access to health and education, and establish institutions and lasting partnerships. Generally, the effectiveness of any country in trying to achieve the SDGs depends to a large extent on its leadership (Meuleman 2021; Yadav et al. 2021). The world needs effective leadership for sustainable development, and that leadership requires an internal process in which a leader must first build on self-understanding and a relative worldview in order to work effectively with others to bring about change. Moreover, because sustainable leaders consider long-term aspects, systems thinking and management development are key to sustainability (Shaked and Schechter 2020). Organizations are motivated to use sustainable practices as a business strategy to achieve long-term business (Haessler 2020).

The nature of the SDGs and the 2030 Agenda establishes a detailed framework within which companies can focus on specific and relevant areas or themes, and then set goals to increase their impact on sustainable development. The main motivation is to provide a neutral and creative space, alongside formal processes, where leaders from different sectors and backgrounds can connect to collaborate and take the next bold steps toward achieving the SDGs. Pursuing each SDG should come together to drive action under each goal, while expanding opportunities for collaboration between the goals. This ranged from new approaches to advancing intergenerational learning groups, networks for women leaders working for gender equality in faith-based settings, and communities of practice for the next generation of education, leadership and innovation on the SDGs. It is important to create a new and rewarding environment for addressing challenges across all SDGs and this is especially relevant in the times of the COVID-19 pandemic. By using a universal agenda our efforts will help create an environment in which other organizations are encouraged to embrace the same goals, create an environment for information sharing, and take more effective steps to achieve the SDGs. While respecting the three dimensions of universality, integration and interconnection, and sustainable development, all countries will continue to make progress in achieving universal goals and objectives, including the means of implementation. They have set an agenda for achieving inclusive economic growth by 2030 and have received input from companies, universities, and non-profit organizations around the world. Today, all CEOs would declare that sustainable development is critical to the success of their company (Khoshnava et al. 2019; Lu et al. 2019; Westerman et al. 2021). The company formulates sustainable development strategies, markets sustainable products and services, establishes sustainability manager positions, and serves consumers, investors, green activists as well as the public by releasing a sustainability report publicly. Sustainable leadership practices, such as management development, long-term employment, knowledge sharing, and innovation systems, will generate a high degree of organizational learning tendency, which will further lead to a high degree of civic behavior in the organization (Kim and Park 2019). According to Iqbal et al. (2020), sustainable leaders exhibit six core practices, such as innovation, talent development, long-term vision, ethical behavior, organizational culture, and social and environmental responsibility. In the context of sustainable development, learning organizations face sustainability challenges in terms of social, environmental, and environmental requirements in a dynamic and complex market, and new methods, policies, and structures are imperative (Da Giau et al. 2020). Management methods and new leadership styles show that the understanding of the importance of relationships and the establishment of positive storytelling in the organizational environment are the keys to mobilizing energy, solving problems, and promoting the sustainable development and well-being of the people in the organization. Innovative leadership and governance are essential for organizations in all sectors to incorporate these sustainable development goals into strategic plans and operations that serve the aspirations of 2030. 
Sustainable design offers something that does not exist yet; change existing in accordance with new goals to achieve new results and transfers knowledge and solutions to solve new problems (Schot and Steinmueller 2018; Fogarassy and Finger 2020). According to the new point of view, creating and managing a sustainable project is based not only on the use of increasingly diminishing volumes of resources, but also on their restoration (Barbier 2020). This has serious implications for the long-term sustainable success of companies.

In general terms, the COVID-19 pandemic demonstrated the interdependence of all nations around the world in the face of the global warming and climate change. Figure 2 that follows depicts the linkages between the climate change and future disasters and pandemic (just like COVID-19 or perhaps even worse) that might be caused by the reckless human behavior and the exploitation of the natural resources and lead to migration crises or other disasters (Glazar and Strielkowski 2010). The threat of future pandemics and economic shocks underscores the need for robust distance education both to prepare for the next global health emergency and to bridge the long-standing divide in socioeconomic education.

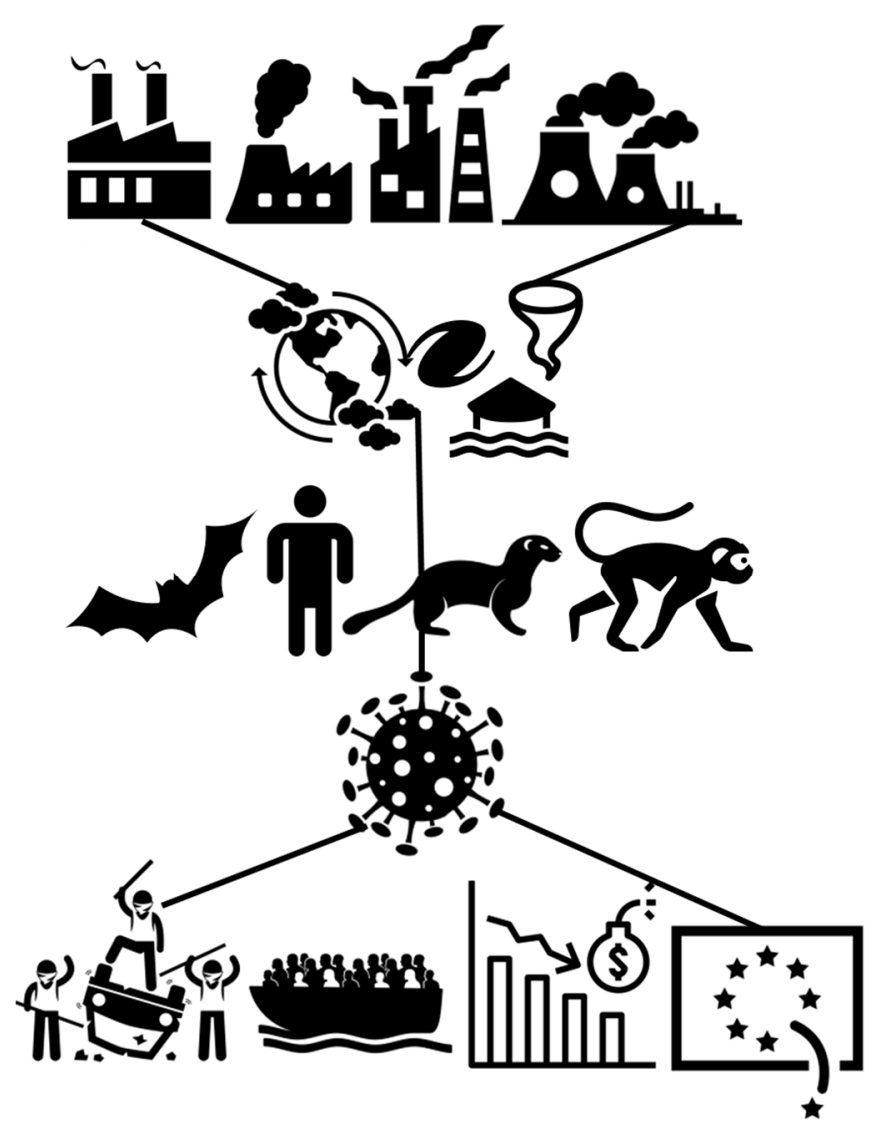

Figure 2. COVID-19 and future pandemics. Source: own results.

Therefore, this agenda, including the SDGs can be implemented through a new global partnership for sustainable development and is supported by specific policies and actions outlined in recent action agendas. Governments worldwide should all strive to implement the agenda at their national, regional, and global levels, taking into account different national realities, opportunities and development levels, and respecting national policies and priorities. This should be done with respect to the national policy space for sustainable policies, inclusiveness, and sustainable economic growth, especially for developing countries, while maintaining compliance with relevant international standards and commitments. 


\section{Empirical Model: Measuring the Adaptation Processes}

In this empirical part of our paper, we aim to back up our theoretical findings with the data and modelling. In particular, we are focusing on investigating how the business and economic leaders of today are adapting to the new reality by searching for new ways of business and personal development during and after the COVID-19 pandemic.

As it has been already mentioned in the introductory part of this paper, the main criteria of this research and its instrumentation is based on the empirical analysis that supports the theoretical provisions and discussion stemming from the literature review. Our theoretical research demonstrated that there are new perspectives emerging in the sustainable leadership and organizational resilience domains in the post-pandemic economic and business landscape. Our instrumentation used to capture these perspectives is centered around the concept of the emotional creativity (consisting of the four elements represented by the novelty, preparedness, effectiveness, and authenticity) and its connection to the motivation for learning and adopting novel digital technologies and ICTs in people's daily lives and jobs. It has been shown recently that creativity strongly influences organizational innovation as well as has an impact on organizational learning and adaptation strategies in times like the COVID-19 pandemic crisis (Azizi et al. 2021; Carayannis et al. 2021; Hutajulu et al. 2021). In addition, emotional creativity represents one of the main three parts of the concept of creativity (Hughes et al. 2018) and is reported to have a significant impact on work motivation and improvement (Wang et al. 2015), hence it can be used as a dependent variable in our empirical model that is explained below in greater detail.

Our data comes from the own survey administered in the Czech Republic and Russian Federation between September 2020 and March 2021. Both countries have been selected not on random but due to their specificities. Both states represent post-Communist, Slavicspeaking countries that embarked on the path of economic transition over 30 years ago, however the track of their development has started to differ due to the economic, social, and geopolitical reasons. While the Czech Republic became a Member State of the European Union in 2004 and integrated itself into the European structures, Russia has chosen a somewhat different path cooperating with Brazil, India, and China and creating the Eurasian Economic Union (EAEU) with the post-Soviet countries. Moreover, the level of digitalization and e-government participation in both countries is quite different with Russia lagging behind the Czech Republic in the early 2000s but quickly catching up and implementing digitalization and e-participation by the early 2020s (United Nations 2021). Hence, we have decided to utilize these differences and similarities in our study which has been also reinforced by our work in these two countries in question that enabled us to conduct a well-planned and well-executed data collection and analysis. The method of sampling was quasi-random and included both the elements of the snowball technique as well as the opportunity sampling. The participants were recruited both personally using social networks and online modes of communication and via the e-mail.

In total, we obtained a sample of 400 respondents from the Czech Republic (136 respondents) and Russian Federation (264 respondents), 58\% women and $42 \%$ men $(\mathrm{M} \pm \mathrm{SD}=45.53 \pm 11.46$, median 44$)$ who completed our questionnaire voluntarily and anonymously. All the respondents had higher degree education (master's degree or higher). The positions, best describing their work duties at the universities, included managers $(73 \%)$, analysts (14\%), and top managers represented by CEOs and CFOs (13\%). The companies represented by their managers and analysts in the sample were mostly from business, finance, accounting, and consulting $(71 \%)$, followed by the ICT companies $(15 \%)$, education providers such as private schools and universities (11\%), and other services (3\%).

The survey featured a number of questions but only several of them were used in this paper. The questions were composed on a 5-point scale, which ranged from 1 (strongly agree) to 5 (strongly disagree).

Table 1 that follows reports the cross-tabulation of the responses by countries showing the motivation to start home office to enhance productivity. 
Table 1. Motivation to start home office to enhance productivity (cross-tabulations of responses by countries).

\begin{tabular}{|c|c|c|c|c|c|c|c|c|}
\hline & & & 1-Disagree $^{a}$ & $2^{a}$ & $3^{a}$ & $4^{a}$ & 5 -Agree ${ }^{a}$ & Total \\
\hline Country & Czech Republic & $\%$ within country & $29.9 \%$ & $15.3 \%$ & $29.9 \%$ & $15.3 \%$ & $9.5 \%$ & $100 \%$ \\
\hline & Russian Federation & $\%$ within country & $21.9 \%$ & $19.6 \%$ & $21.5 \%$ & $18.9 \%$ & $18.1 \%$ & $100 \%$ \\
\hline Total & & $\%$ within country & $25.1 \%$ & $17.3 \%$ & $25.7 \%$ & $17.1 \%$ & $14.9 \%$ & $100 \%$ \\
\hline
\end{tabular}

Note: ${ }^{a}$ The pandemic made me to start home office to enhance productivity, 1—strongly disagree, 5—strongly agree. Source: Own results.

One can see that even though the COVID-19 pandemic had an impact on switching to the home office online mode of work (in a number of cases the companies had no choice as far as strict lockdowns were imposed), it is highly likely that it was not the main driver of this switch as far as the home office (or the hybrid mode of work) has been in use in many companies already before the pandemic. It might be that the pandemic pushed many companies to embracing this mode of work several years before they would actually consider doing it themselves entirely and at their own initiative.

Table 2 that follows demonstrates the results of the cross-tabulations of the responses covering the motivation to use novel technology (such as information and communication tools represented by the teleconferencing software, online business solutions, virtual reality (VR) or augmented reality (AR)) for looking for business partners in other cities or abroad. Tools such as VR or AR can offer many interesting solutions such as demonstrating the prototypes of products online and working on various technological and business aspects remotely at lower costs.

Table 2. Motivation to use novel technology for looking for business partners in other cities or abroad (cross-tabulations of responses by countries).

\begin{tabular}{|c|c|c|c|c|c|c|c|c|}
\hline & & & 1-Disagree ${ }^{a}$ & $2^{a}$ & $3^{a}$ & $4^{a}$ & 5-Agree ${ }^{a}$ & Total \\
\hline \multirow{2}{*}{ country } & Czech Republic & $\%$ within country & $32.1 \%$ & $27 \%$ & $24.8 \%$ & $12.4 \%$ & $3.6 \%$ & $100 \%$ \\
\hline & Russian Federation & $\%$ within country & $35.8 \%$ & $23.8 \%$ & $27.2 \%$ & $7.5 \%$ & $5.7 \%$ & $100 \%$ \\
\hline Total & & $\%$ within country & $32.2 \%$ & $24.4 \%$ & $29.2 \%$ & $9.9 \%$ & $4.3 \%$ & $100 \%$ \\
\hline
\end{tabular}

Note: ${ }^{\text {a }}$ The pandemic motivated me to use ICT for looking for partners for conducting business in other cities or abroad, 1 —strongly disagree, 5—strongly agree. Source: Own results.

Furthermore, we apply the ordinal regression analysis in order to test the relationships between emotional creativity (ECI) and its components on one side and motivations to look for new ways of doing business and developing novel ways to conduct this business during the COVID-10 pandemic on the other side. The topic of ECI has been a focus of many similar papers (see e.g., Ćábelková et al. 2020). Similar to other related papers, we also control for age, gender, country, type of business, and type of activity best describing the job position within a company. Our formal model can be presented in a form of the following Equation (1):

motivation $=$ logit $\left(\alpha_{0} E C I+\alpha_{1}\right.$ Age $+\alpha_{2}$ Gender $+\alpha_{3}$ Country $+\alpha_{4}$ businesstype $+\alpha_{5}$ position $\left.+e\right)$

where:

motivation-indicators of motivation;

emotional creativity (ECI) - measured by its subscales of novelty, preparedness and effectiveness/authenticity subsequently;

age-age of the respondent;

gender-gender of the respondent

country-country of the respondent

businesstype - type of business (business, finance, accounting and consulting, ICT, education, or other)

Position — position at the university which best describes the job: lecturer, researcher, manager' 
$e$-is an error term.

Table 3 that follows reports the results of the empirical model estimation. We assess the ECI across five different fields such as technological enhancement within a company, online and digital collaboration, reaching out to new business partners both at the national and international level using ICT and other advanced technologies, adapting the ICT in the daily operation and business, and business development using the novel approaches.

Table 3. Emotional creativity (ECI) for improving motivation for the novel ways of doing business during the COVID-19 pandemic (ordinal regression analysis).

\begin{tabular}{|c|c|c|c|c|c|c|c|c|c|c|}
\hline & \multicolumn{2}{|c|}{$\begin{array}{l}\text { Technological } \\
\text { Enhancement }\end{array}$} & \multicolumn{2}{|c|}{ Online Collaboration } & \multicolumn{2}{|c|}{ Business Partners } & \multicolumn{2}{|c|}{ Novel Technologies } & \multicolumn{2}{|c|}{$\begin{array}{c}\text { Business } \\
\text { Development }\end{array}$} \\
\hline & Estimate & Sig. & Estimate & Sig. & Estimate & Sig. & Estimate & Sig. & Estimate & Sig. \\
\hline Threshold 1 & 2.375 & 0.101 & -0.283 & 0.908 & 0.911 & 0.396 & 2.263 & 0.237 & 2.610 & 0.063 \\
\hline Threshold 2 & 3.096 & 0.008 & 0.893 & 0.396 & 2.976 & 0.027 & 3.213 & 0.006 & 3.620 & 0.002 \\
\hline Threshold 3 & 4.300 & 0.000 & 2.951 & 0.027 & 4.377 & 0.000 & 4.886 & 0.000 & 4.396 & 0.000 \\
\hline Threshold 4 & 5.225 & 0.000 & 4.247 & 0.000 & 5.794 & 0.000 & 6.133 & 0.000 & 5.787 & 0.000 \\
\hline ECI & $0.035^{* * *}$ & 0.000 & $0.033^{* * *}$ & 0.000 & $0.035^{* * *}$ & 0.000 & $0.042^{* * *}$ & 0.000 & $0.028 * *$ & 0.043 \\
\hline Age & -0.005 & 0.525 & $-0.027^{*}$ & 0.046 & -0.006 & 0.625 & -0.024 & 0.101 & -0.021 & 0.218 \\
\hline $\begin{array}{l}\text { Gender (men) } \\
\text { Country }\end{array}$ & -0.057 & 0.898 & -0.301 & 0.364 & 0.205 & 0.667 & 0.219 & 0.622 & 0.451 & 0.064 \\
\hline Czechia & -0.287 & 0.467 & 0.341 & 0.345 & 0.287 & 0.477 & 0.256 & 0.557 & $0.776^{* *}$ & 0.002 \\
\hline Educ & 0.485 & 0.366 & 0.546 & 0.296 & 0.051 & 0.904 & 0.409 & 0.478 & 0.371 & 0.536 \\
\hline ICT & 0.858 & 0.087 & -0.043 & 0.949 & -0.363 & 0.658 & -0.047 & 0.956 & 0.051 & 0.967 \\
\hline BusEcon & 0.811 * & 0.037 & 0.351 & 0.746 & -0.493 & 0.449 & -0.381 & 0.682 & 0.093 & 0.850 \\
\hline Manager & -0.081 & 0.921 & -0.575 & 0.240 & -0.546 & 0.092 & $\begin{array}{c}-0.835 \\
* *\end{array}$ & 0.006 & 0.487 & 0.248 \\
\hline Analyst & -0.353 & 0.544 & -0.009 & 0.991 & -0.256 & 0.743 & -0.721 & 0.075 & 0.754 & 0.067 \\
\hline Cox and Snell & 0.077 & & 0.069 & & 0.070 & & 0.080 & & 0.075 & \\
\hline Nagelkerke & 0.079 & & 0.062 & & 0.064 & & 0.096 & & 0.078 & \\
\hline McFadden & 0.032 & & 0.039 & & 0.032 & & 0.043 & & 0.033 & \\
\hline $\begin{array}{l}\text { Sig. } \\
\text { N }\end{array}$ & & 0.000 & & 0.001 & 400 & 0.002 & & 0.000 & & 0.002 \\
\hline
\end{tabular}

Note: Reference Variables: gender (women); country (Russian Federation); position. Link function: logit. *** Significant at the 0.01 level; ${ }^{* *}$ Significant at the 0.05 level; ${ }^{*}$ Significant at the 0.1 level. Source: Own results.

From the findings depicted in the table it can be seen that ECI variable comes through as significant in all cases. Additionally, it becomes obvious that both emotional creativity and its components (novelty, preparedness, effectiveness/authenticity) proved to be positively associated to motivations of new ways of doing business and undertaking one's personal development while the age was negatively related to the motivation of learning and embracing the online technologies.

Our results seem to confirm the notion that the COVID-19 pandemic has accelerated the changes in digital use that were already taking place before the virus started to spread. Many business companies already considered massive digitalization or hybrid or remote work but were reluctant to try either due to the legal restrictions or the technological concerns. The pandemic removed these barriers and showed that, in fact, many companies were prepared for the digital surge and benefited from it.

The burden falls both on each individual to change their behavior and on organizations to prevent overconsumption and reduce waste to ensure a sustainable and healthy future. In a world torn apart by pandemics, climate change and civil unrest, we need responsible business leaders who act in the public interest.

Our results reveal that that sustainable economic and business development requires leaders who can develop approaches, policies, and programs to promote socially and organizationally sustainable practices and drive economic success as well as economic performance (which are both important economic aspects). Resilient leaders have the courage to challenge traditional approaches and the willingness to change their business and industry. Organizations are motivated to use sustainable practices as a business strategy to achieve long-term business. In essence, they are simplifying this complexity in order to make targeted decisions and actions that turn sustainability into a competitive advantage. 
This means that employees also perceive the same presence of these constructs in their organizations. Wise leaders are encouraged to embody honesty and stay away from hypocrisy, accept the truth and stay away from vanity. Organizations measure sustainable performance by simultaneously monitoring economic, social, and environmental performance. Thus, the indirect impact of sustainable leadership on sustainable performance through organizational learning changes in the presence of different mental competency values.

\section{Conclusions}

Overall, it becomes apparent that economic and business leaders around the world need to use the COVID-19 pandemic crisis to rethink their supply networks, take steps to understand their vulnerabilities, and then take action to build resilience. They have to find ways to improve their business and give themselves an edge. Part of a big reboot, as companies and countries see the future post-COVID-19, is rethinking how technology can meet human needs. As workforce safety and resilience, cost management and organizational flexibility become top priorities in the short and long term in the 21st century, the pandemic has heightened old corporate concerns and spawned new ones. After the massive devastation caused by the COVID-19 crisis in 2020, companies are seeking to get back on track and, most importantly, build the future. The COVID-19 pandemic has disrupted everything from consumer behavior to the supply chain, and the economic impact is driving further changes. The economic shock brought about by the epidemic has exposed many vulnerabilities in the supply chain and raised questions about globalization. The unprecedented nature of the pandemic and its economic impact mean that companies may have to make changes as the situation evolves. New technologies will soon allow companies to reduce costs or switch more flexibly between manufactured products, making the base of previous competitors or suppliers obsolete. The pandemic has made automation all the more attractive as social distancing in factories has become a necessity. As the experience of many countries around the world shows, creating new infrastructure for suppliers in another country or region will require a significant investment of time and money. In addition, disruptions and shortages during the COVID-19 pandemic exposed weaknesses in global supply chains that are already facing the threat of trade wars. The COVID-19 pandemic created significant challenges for financial institutions in both modeling and modeling risk management. Organizations have made major changes in response to the pandemic, and there is no turning back. The COVID-19 pandemic has accelerated digital transformation in the majority of organizations with most of them being able to implement initiatives that had previously met with resistance. In a way, the COVID-19 pandemic accelerated digital transformation in the majority of organizations regardless of their profile or scope.

Furthermore, we all should also be concerned with the global warming and the climate change which represent a tsunami (while the pandemic can be viewed as a large tide wave). Within the face of the post-COVID-19 pandemic it is also necessary to redefine the leadership in the business and economic fields to redraft the subject and place it in the context of the Sustainable Development Goals. Hence, it is crucial to seek for business and economic benefits from a variety of perspectives and perspectives such as economic theory, management, marketing, behavioral economics, institutional economics, political economics, agricultural economics, international trade, labor economics, or ecology for better learning a new understanding of leadership in business and economics.

Our work highlights the importance of sustainable thinking, the purposeful belief that business is not a commercial activity, separate from the wider social and environmental context in which it operates. Our results might be useful for the political decision-makers, mid-level professionals, technical officials, national planning, sustainable development, finance, social protection agencies, development professionals, NGO leaders, business leaders, and corporate social responsibility of private sector companies (CSR) as well as social workers working as project managers. This opens up opportunities for new areas of research and intervention, namely management and organizational resilience, psychology, 
or the sustainable development of organizational well-being. The COVID-19 pandemic continues to test the overall resilience of organizations around the world by minimizing disruption in times of crisis through organizational resilience. Despite its adverse impact on businesses, the pandemic has clearly demonstrated the importance of organizational resilience. Management must ensure that they focus on areas that will have the greatest impact on organizational sustainability. Many organizations plan for disaster recovery, such as what to do in the event of a flood or earthquake. However, few organizations have a contingency plan for a global pandemic that keeps most of the world's population at home locked up in a series of lockdowns and working remotely on a home office.

By building resilience around where and how employees work with technology, we can gain experience that can be directly applied in times of crisis. There are nonmonetary values that include social working conditions, loyalty and, in particular, longterm employment relationships that represent the employee-centered approach which in turn leads to increased organizational resilience. Our results show that during the unexpected outbreak of the COVID-19 pandemic, larger companies, industry professionals, and business and economic leaders with stronger client ties demonstrate higher levels of resilience and are able to maintain expected performance levels. Each feature has not only helped them through the COVID-19 crisis, but now also points the way to a more flexible operating model that can be more resilient under the next normal conditions.

Our research provides executives with some novel theoretical insights (based on both the theoretical implications and the empirical findings) into the post-pandemic business landscape, providing new perspectives on digital transformation, the future of work, transparency, and sustainability in the light of sustainable leadership, organizational resilience, and the Industry 5.0 concept. Together, they provide guidance for proactive leaders who understand that the old way of working is a thing of the past. It is remarkable how the pandemic is accelerating the adoption of external data and transforming data scientists into amateur epidemiologists. This is why the companies should not throw out edge data, and why working with data may be more important than ever. In order to invest into sustainability, organizations must understand their strengths and weaknesses and must be able to evaluate the effectiveness of sustainability strategies. Our research shows that an organization that has resilient people, systems, and processes can adapt with greater confidence to the diverse needs of its market, so having an organization-centric measure of resilience is important. This will then enable organizations to demonstrate the business case for sustainability and demonstrate the added value of a sustainability management program. This shows a clear link between organizational resilience and business performance.

In 2022 and beyond (which is already turning into the third year of the pandemic), the impact of the COVID-19 pandemic on wages will continue to vary by sector, region, and company. As the virus have been raging for some time now and claiming the lives of hundreds of thousands of people, many industries realized how important their hourly workforce is to keeping the nation's business and economy alive. Thus, the pandemic ushered in an era of innovations, hybrid jobs and rejections that some regions are experiencing now, as options lead to new spikes in cases. Digital disruption already made widespread multidimensional uncertainty the new norm in the 2010s but it was the COVID-19 pandemic that overturned any definition of normality and set the pathways for the future development of the novel forms of leadership in business and economics.

Author Contributions: Conceptualization, W.S., I.F., S.A. and I.S.; methodology, W.S. and I.F.; formal analysis, W.S., I.F., S.A. and I.S.; investigation, W.S.; resources, S.A. and I.S.; data curation, W.S., I.F., S.A. and I.S.; writing - original draft preparation, W.S., I.F., S.A. and I.S.; supervision, W.S.; project administration, W.S., I.F., S.A. and I.S.; funding acquisition, W.S., I.F., S.A. and I.S. All authors have read and agreed to the published version of the manuscript.

Funding: This research did not receive any funding.

Institutional Review Board Statement: Not applicable. 
Informed Consent Statement: Informed consent was obtained from all subjects involved in the study.

Conflicts of Interest: The authors declare no conflict of interest.

\section{References}

Ahmad, Wasim, Ali M. Kutan, and Smarth Gupta. 2021. Black swan events and COVID-19 outbreak: Sector level evidence from the US, UK, and European stock markets. International Review of Economics \& Finance 75: 546-57. [CrossRef]

Anderson, Monica, and Emily Vogels. 2020. Americans Turn to Technology during COVID-19 Outbreak, Say an Outage Would Be a Problem. Available online: https:/ / www.pewresearch.org/fact-tank/2020/03/31/americans-turn-to-technology-during-covid19-outbreak-say-an-outage-would-be-a-problem (accessed on 21 December 2021).

Ansell, Christopher, Eva Sørensen, and Jacob Torfing. 2021. The COVID-19 pandemic as a game changer for public administration and leadership? The need for robust governance responses to turbulent problems. Public Management Review 23: 949-60. [CrossRef]

Arsawan, I. Wayan Edi, Viktor Koval, Ismi Rajiani, Ni Wayan Rustiarini, Wayan Gede Supartha, and Ni Putu Santi Suryantini. 2020. Leveraging knowledge sharing and innovation culture into SMEs sustainable competitive advantage. International Journal of Productivity and Performance Management. ahead-of-print. [CrossRef]

Aslam, Farhan, Wang Aimin, Mingze Li, and Khaliq Ur Rehman. 2020. Innovation in the era of IoT and industry 5.0: Absolute innovation management (AIM) framework. Information 11: 124. [CrossRef]

Avery, Gayle C., and Harald Bergsteiner. 2011. How BMW successfully practices sustainable leadership principles. Strategy E Leadership 39: 11-18. [CrossRef]

Azizi, Mohammad Reza, Rasha Atlasi, Arash Ziapour, Jaffar Abbas, and Roya Naemi. 2021. Innovative human resource management strategies during the COVID-19 pandemic: A systematic narrative review approach. Heliyon 7: e07233. [CrossRef]

Azubuike, Obiageri Bridget, Oyindamola Adegboye, and Habeeb Quadri. 2021. Who gets to learn in a pandemic? Exploring the digital divide in remote learning during the COVID-19 pandemic in Nigeria. International Journal of Educational Research Open 2: 100022. [CrossRef]

Bai, John Jianqiu, Erik Brynjolfsson, Wang Jin, Sebastian Steffen, and Chi Wan. 2021. Digital Resilience: How Work-From-Home Feasibility Affects Firm Performance. Paper No. W28588. National Bureau of Economic Research. Available online: https: //www.nber.org/papers/w28588 (accessed on 20 December 2021).

Baptista, João, Mari-Klara Stein, Stefan Klein, Mary Beth Watson-Manheim, and Jungwoo Lee. 2020. Digital work and organisational transformation: Emergent digital/human work configurations in modern organisations. The Journal of Strategic Information Systems 29: 101618. [CrossRef]

Barbier, Edward. 2020. Greening the post-pandemic recovery in the G20. Environmental and Resource Economics 76: 685-703. [CrossRef]

Bennett, Kieran, and Mohammad Mayouf. 2021. Value Management Integration for Whole Life Cycle: Post COVID-19 Strategy for the UK Construction Industry. Sustainability 13: 9274. [CrossRef]

Bennett, Elisabeth E., and Rochell R. McWhorter. 2021. Virtual HRD's role in crisis and the post Covid-19 professional lifeworld: Accelerating skills for digital transformation. Advances in Developing Human Resources 23: 5-25. [CrossRef]

Bieck, Christian, and Anthony Marshall. 2020. Redirecting resources to promote post-pandemic growth. Strategy and Leadership 48: 45-50. [CrossRef]

Brown, Charlotte, Erica Seville, and John Vargo. 2017. Measuring the organizational resilience of critical infrastructure providers: A New Zealand case study. International Journal of Critical Infrastructure Protection 18: 37-49. [CrossRef]

Brown, Charlotte, Erica Seville, Tracy Hatton, Joanne Stevenson, Nicola Smith, and John Vargo. 2019. Accounting for business adaptations in economic disruption models. Journal of Infrastructure Systems 25: 04019001. [CrossRef]

Čábelková, Inna, Strielkowski Wadim, Rybakova Anna, and Alla Molchanova. 2020. Does Playing Video Games Increase Emotional Creativity? International Journal of Environmental Research and Public Health 17: 2177. [CrossRef] [PubMed]

Cao, Xiaole, Yao Xiong, Jia Sun, Xiaoxiao Zhu, Qijun Sun, and Zhong Lin Wang. 2021. Piezoelectric Nanogenerators Derived Self-Powered Sensors for Multifunctional Applications and Artificial Intelligence. Advanced Functional Materials 31: 2102983. [CrossRef]

Carayannis, Elias G., David FJ Campbell, and Evangelos Grigoroudis. 2021. Helix Trilogy: The Triple, Quadruple, and Quintuple Innovation Helices from a Theory, Policy, and Practice Set of Perspectives. Journal of the Knowledge Economy 6: 1-30. [CrossRef]

Casola, Valentina, Alessandra De Benedictis, Massimiliano Rak, and Umberto Villano. 2020. A novel Security-by-Design methodology: Modeling and assessing security by SLAs with a quantitative approach. Journal of Systems and Software 163: 110537. [CrossRef]

Cillo, Valentina, Gian Luca Gregori, Lucia Michela Daniele, Francesco Caputo, and Nathalie Bitbol-Saba. 2021. Rethinking companies' culture through knowledge management lens during Industry 5.0 transition. Journal of Knowledge Management. ahead-of-print. [CrossRef]

Cobbinah, Patrick Brandful, Eric Gaisie, Nana Yaw Oppong-Yeboah, and Desmond Ofosu Anim. 2020. Kumasi: Towards a sustainable and resilient cityscape. Cities 97: 102567. [CrossRef]

Cone, Lucas, Katja Brøgger, Mieke Berghmans, Mathias Decuypere, Annina Förschler, Emiliano Grimaldi, Sigrid Hartong, Thomas Hillman, Malin Ideland, Paolo Landri, and et al. 2021. Pandemic Acceleration: Covid-19 and the emergency digitalization of European education. European Educational Research Journal. online first. [CrossRef] 
Culot, Giovanna, Guido Orzes, and Marco Sartor. 2019. Integration and scale in the context of Industry 4.0: The evolving shapes of manufacturing value chains. IEEE Engineering Management Review 47: 45-51. [CrossRef]

Czech, Katarzyna, Anna Davy, and Michał Wielechowski. 2021. Does the COVID-19 Pandemic Change Human Mobility Equally Worldwide? Cross-Country Cluster Analysis. Economies 9: 182. [CrossRef]

D'Adamo, Idiano, and Paolo Rosa. 2020. How Do You See Infrastructure? Green Energy to Provide Economic Growth after COVID-19. Sustainability 12: 4738. [CrossRef]

Da Giau, Alessandro, Nicolai J. Foss, Andrea Furlan, and Andrea Vinelli. 2020. Sustainable development and dynamic capabilities in the fashion industry: A multi-case study. Corporate Social Responsibility and Environmental Management 27: 1509-20. [CrossRef]

Dannenberg, Peter, Martina Fuchs, Tim Riedler, and Cathrin Wiedemann. 2020. Digital transition by COVID-19 pandemic? The German food online retail. Tijdschrift Voor Economische En Sociale Geografie 111: 543-60. [CrossRef]

De Sousa Jabbour, Ana Beatriz Lopes, Charbel Jose Chiappetta Jabbour, Martin Hingley, Eliseo Luis Vilalta-Perdomo, Gary Ramsden, and David Twigg. 2020. Sustainability of supply chains in the wake of the coronavirus (COVID-19/SARS-CoV-2) pandemic: Lessons and trends. Modern Supply Chain Research and Applications 2: 117-22. [CrossRef]

Domínguez-Escrig, Emilio, Francisco Fermín Mallén-Broch, Rafael Lapiedra-Alcamí, and Ricardo Chiva-Gómez. 2019. The influence of leaders' stewardship behavior on innovation success: The mediating effect of radical innovation. Journal of Business Ethics 159: 849-62. [CrossRef]

Donthu, Naveen, and Anders Gustafsson. 2020. Effects of COVID-19 on business and research. Journal of Business Research 117: $284-89$. [CrossRef]

Duchek, Stephanie. 2020. Organizational resilience: A capability-based conceptualization. Business Research 13: 215-46. [CrossRef]

Duit, Andreas. 2016. Resilience thinking: Lessons for public administration. Public Administration 94: 364-80. [CrossRef]

Fernando, Yudi, Charbel Jose Chiappetta Jabbour, and Wen-Xin Wah. 2019. Pursuing green growth in technology firms through the connections between environmental innovation and sustainable business performance: Does service capability matter? Resources, Conservation and Recycling 141: 8-20. [CrossRef]

Fink, Lior. 2020. Conducting information systems research in the midst of the COVID-19 pandemic: Opportunities and challenges. Information Systems Management 37: 256-59. [CrossRef]

Fogarassy, Csaba, and David Finger. 2020. Theoretical and practical approaches of circular economy for business models and technological solutions. Resources 9: 76. [CrossRef]

Gabryelczyk, Renata. 2020. Has COVID-19 Accelerated Digital Transformation? Initial Lessons Learned for Public Administrations. Information Systems Management 37: 303-9. [CrossRef]

Gereffi, Gary. 2020. What does the COVID-19 pandemic teach us about global value chains? The case of medical supplies. Journal of International Business Policy 3: 287-301. [CrossRef]

Glavič, Peter. 2021. Evolution and Current Challenges of Sustainable Consumption and Production. Sustainability 13: 9379. [CrossRef]

Glazar, Ondrej, and Wadim Strielkowski. 2010. Turkey and the European Union: Possible incidence of the EU accession on migration flows. Prague Economic Papers 19: 218-35. [CrossRef]

Golan, Maureen S., Laura H. Jernegan, and Igor Linkov. 2020. Trends and applications of resilience analytics in supply chain modeling: Systematic literature review in the context of the COVID-19 pandemic. Environment Systems and Decisions 40: 222-43. [CrossRef]

Goniewicz, Krzysztof, Amir Khorram-Manesh, Attila J. Hertelendy, Mariusz Goniewicz, Katarzyna Naylor, and Frederick M. Burkle. 2020. Current response and management decisions of the European Union to the COVID-19 outbreak: A review. Sustainability 12: 3838. [CrossRef]

Gorjian Khanzad, Zahra, and Ali A. Gooyabadi. 2021. Development of Strategic Resilience Framework for Small Businesses PostCOVID-19. Businesses 1: 127-41. [CrossRef]

$\mathrm{Gu}$, Shengyu, Beata Ślusarczyk, Sevda Hajizada, Irina Kovalyova, and Amina Sakhbieva. 2021. Impact of the covid-19 pandemic on online consumer purchasing behavior. Journal of Theoretical and Applied Electronic Commerce Research 16: 2263-81. [CrossRef]

Haessler, Philipp. 2020. Strategic Decisions between Short-Term Profit and Sustainability. Administrative Sciences 10: 63. [CrossRef]

Hall, Michael. 2019. Constructing sustainable tourism development: The 2030 agenda and the managerial ecology of sustainable tourism. Journal of Sustainable Tourism 27: 1044-60. [CrossRef]

Hallinger, Philip. 2020. Science mapping the knowledge base on educational leadership and management from the emerging regions of Asia, Africa and Latin America, 1965-2018. Educational Management Administration and Leadership 48: 209-30. [CrossRef]

Hallinger, Philip, and Suparak Suriyankietkaew. 2018. Science Mapping of the Knowledge Base on Sustainable Leadership, 1990-2018. Sustainability 10: 4846. [CrossRef]

Hughes, David J., Allan Lee, Amy Wei Tian, Alex Newman, and Alison Legood. 2018. Leadership, creativity, and innovation: A critical review and practical recommendations. The Leadership Quarterly 29: 549-69. [CrossRef]

Hutajulu, Richard Surungan, Dewi Susita, and Anis Eliyana. 2021. The Effect of Digitalization and Virtual Leadership on Organizational Innovation During the COVID-19 Pandemic Crisis: A Case Study in Indonesia. The Journal of Asian Finance, Economics and Business 8: 57-64. [CrossRef]

Hynes, William, Benjamin Trump, Patrick Love, and Igor Linkov. 2020. Bouncing forward: A resilience approach to dealing with COVID-19 and future systemic shocks. Environment Systems and Decisions 40: 174-84. [CrossRef] [PubMed] 
Ibn-Mohammed, Taofeeq, K. B. Mustapha, J. Godsell, Z. Adamu, K. A. Babatunde, D. D. Akintade, Adolf Acquaye, H. Fujiih, M. M. Ndiayei, F. A. Yamoahj, and et al. 2021. A critical analysis of the impacts of COVID-19 on the global economy and ecosystems and opportunities for circular economy strategies. Resources, Conservation and Recycling 164: 105169. [CrossRef]

Iivari, Netta, Sumita Sharma, and Leena Ventä-Olkkonen. 2020. Digital transformation of everyday life-How COVID-19 pandemic transformed the basic education of the young generation and why information management research should care? International Journal of Information Management 55: 102183. [CrossRef] [PubMed]

Iqbal, Qaisar, Noor Hazlina Ahmad, Adeel Nasim, and Syed Abdul Rehman Khan. 2020. A moderated-mediation analysis of psychological empowerment: Sustainable leadership and sustainable performance. Journal of Cleaner Production 262: 121429. [CrossRef]

Irawanto, Dodi Wirawan, Khusnul Rofida Novianti, and Kenny Roz. 2021. Work from home: Measuring satisfaction between work-life balance and work stress during the COVID-19 pandemic in Indonesia. Economies 9: 96. [CrossRef]

Jakovljevic, Miro, Sarah Bjedov, Nenad Jaksic, and Ivan Jakovljevic. 2020. COVID-19 pandemia and public and global mental health from the perspective of global health security. Psychiatria Danubina 32: 6-14. [CrossRef]

Jankowski, Natasha. 2020. Assessment during a Crisis: Responding to a Global Pandemic. National Institute for Learning Outcomes Assessment. Available online: https:/ / eric.ed.gov/?id=ED608798 (accessed on 12 December 2021).

Javaid, Mohd, Abid Haleem, Ravi Pratap Singh, and Rajiv Suman. 2021. Substantial capabilities of robotics in enhancing industry 4.0 implementation. Cognitive Robotics 1: 58-75. [CrossRef]

Jiang, Yangyang, and Nikolaos Stylos. 2021. Triggers of consumers' enhanced digital engagement and the role of digital technologies in transforming the retail ecosystem during COVID-19 pandemic. Technological Forecasting and Social Change 172: 121029. [CrossRef]

Kamal, Muhammad Mustafa. 2020. The triple-edged sword of COVID-19: Understanding the use of digital technologies and the impact of productive, disruptive, and destructive nature of the pandemic. Information Systems Management 37: 310-17. [CrossRef]

Kanekar, Amar, and Manoj Sharma. 2020. COVID-19 and Mental Well-Being: Guidance on the Application of Behavioral and Positive Well-Being Strategies. Healthcare 8: 336. [CrossRef]

Kantabutra, Sooksan. 2014. Measuring corporate sustainability: A Thai approach. Measuring Business Excellence 18: 73-88. [CrossRef]

Kantabutra, Sooksan, and Nuttasorn Ketprapakorn. 2020. Toward a theory of corporate sustainability: A theoretical integration and exploration. Journal of Cleaner Production 270: 122292. [CrossRef]

Kantabutra, Sooksan, and Nuttasorn Ketprapakorn. 2021. Toward an Organizational Theory of Resilience: An Interim Struggle. Sustainability 13: 13137. [CrossRef]

Keshky, El, Mogeda El Sayed, Sawzan Sadaqa Basyouni, and Abeer Mohammad Al Sabban. 2020. Getting through COVID-19: The pandemic's impact on the psychology of sustainability, quality of life, and the global economy-A systematic review. Frontiers in Psychology 11: 3188. [CrossRef] [PubMed]

Ketprapakorn, Nuttasorn. 2019. Toward an Asian corporate sustainability model: An integrative review. Journal of Cleaner Production 239: 117995. [CrossRef]

Ketprapakorn, Nuttasorn, and Sooksan Kantabutra. 2019a. Culture development for sustainable SMEs: Toward a behavioral theory. Sustainability 11: 2629. [CrossRef]

Ketprapakorn, Nuttasorn, and Sooksan Kantabutra. 2019b. Sustainable social enterprise model: Relationships and consequences. Sustainability 11: 3772. [CrossRef]

Khoshnava, Seyed Meysam, Raheleh Rostami, Rosli Mohamad Zin, Dalia Štreimikienė, Alireza Yousefpour, Wadim Strielkowski, and Abbas Mardani. 2019. Aligning the criteria of green economy (GE) and sustainable development goals (SDGs) to implement sustainable development. Sustainability 11: 4615. [CrossRef]

Kim, Rae Yule. 2020. The impact of COVID-19 on consumers: Preparing for digital sales. IEEE Engineering Management Review 48: 212-18. [CrossRef]

Kim, Eun-Jee, and Sunyoung Park. 2019. The role of transformational leadership in citizenship behavior: Organizational learning and interpersonal trust as mediators. International Journal of Manpower 40: 1347-60. [CrossRef]

Kirk, Colleen P., and Laura S. Rifkin. 2020. I'll trade you diamonds for toilet paper: Consumer reacting, coping and adapting behaviors in the COVID-19 pandemic. Journal of Business Research 117: 124-31. [CrossRef] [PubMed]

Kontogiannis, Tom. 2021. A qualitative model of patterns of resilience and vulnerability in responding to a pandemic outbreak with system dynamics. Safety Science 134: 105077. [CrossRef]

Korneeva, Elena, Nina Olinder, and Wadim Strielkowski. 2021. Consumer Attitudes to the Smart Home Technologies and the Internet of Things (IoT). Energies 14: 7913. [CrossRef]

Kure, Halima Ibrahim, Shareeful Islam, and Mohammad Abdur Razzaque. 2018. An integrated cyber security risk management approach for a cyber-physical system. Applied Sciences 8: 898. [CrossRef]

Lambert, Helen, Jaideep Gupte, Helen Fletcher, Laura Hammond, Nicola Lowe, Mark Pelling, Neelam Raina, Tahrat Shahid, and Kelsey Shanks. 2020. Covid-19 as a global challenge: Towards an inclusive and sustainable future. Lancet Public Health 4: e312-14. [CrossRef]

Lee, Sang M., and DonHee Lee. 2021. Opportunities and challenges for contactless healthcare services in the post-COVID-19 Era. Technological Forecasting and Social Change 167: 120712. [CrossRef] [PubMed]

Lee, Amy V., John Vargo, and Erica Seville. 2013. Developing a tool to measure and compare organizations' resilience. Natural Hazards Review 14: 29-41. [CrossRef] 
Lemieux, Thomas, Kevin Milligan, Tammy Schirle, and Mikal Skuterud. 2020. Initial impacts of the COVID-19 pandemic on the Canadian labour market. Canadian Public Policy 46: S55-65. [CrossRef]

Lenzen, Manfred, Mengyu Li, Arunima Malik, Francesco Pomponi, Ya-Yen Sun, Thomas Wiedmann, Futu Faturay, Jacob Fry, Blanca Gallego, Arne Geschke, and et al. 2020. Global socio-economic losses and environmental gains from the Coronavirus pandemic PLoS ONE 15: e0235654. [CrossRef]

Linnenluecke, Martina. 2017. Resilience in business and management research: A review of influential publications and a research agenda. International Journal of Management Reviews 19: 4-30. [CrossRef]

Linnenluecke, Martina K., Andrew Griffiths, and Monika Winn. 2012. Extreme Weather Events and the Critical Importance of Anticipatory Adaptation and Organizational Resilience in Responding to Impacts. Business Strategy and the Environment 21: 17-32. [CrossRef]

Lu, Jintao, Licheng Ren, Siqin Yao, Jiayuan Qiao, Wadim Strielkowski, and Justas Streimikis. 2019. Comparative review of corporate social responsibility of energy utilities and sustainable energy development trends in the Baltic states. Energies 12: 3417. [CrossRef]

Mandych, Irina, and Anna Bykova. 2021. Difficulties and prospects for the development of high-tech projects in the epoch of digital transformation of economy. Russian Technological Journal 9: 88-95. [CrossRef]

Meuleman, Louis. 2021. Public Administration and Governance for the SDGs: Navigating between Change and Stability. Sustainability 13: 5914. [CrossRef]

Mhlanga, David, and Tankiso Moloi. 2020. COVID-19 and the digital transformation of education: What are we learning on 4IR in South Africa? Education Sciences 10: 180. [CrossRef]

Moawad, Ruba Abdelmatloub. 2020. Online learning during the COVID-19 pandemic and academic stress in university students. Revista Românească pentru Educaţie Multidimensională 12: 100-7. [CrossRef]

Mpungose, Cedric. 2020. Emergent transition from face-to-face to online learning in a South African University in the context of the Coronavirus pandemic. Humanities and Social Sciences Communications 7: 1-9. [CrossRef]

Mukhtar, Khadijah, Kainat Javed, Mahwish Arooj, and Ahsan Sethi. 2020. Advantages, Limitations and Recommendations for online learning during COVID-19 pandemic era. Pakistan Journal of Medical Sciences 36: S27. [CrossRef]

Obermeier, Nina. 2021. COVID-19, economic anxiety, and support for international economic integration. Journal of Elections, Public Opinion and Parties 31: 15-25. [CrossRef]

Obrenovic, Bojan, Jianguo Du, Danijela Godinic, Diana Tsoy, Muhammad Aamir Shafique Khan, and Ilimdorjon Jakhongirov. 2020. Sustaining enterprise operations and productivity during the COVID-19 pandemic: "Enterprise Effectiveness and Sustainability Model". Sustainability 12: 5981. [CrossRef]

Olsen, Tava Lennon, and Brian Tomlin. 2020. Industry 4.0: Opportunities and challenges for operations management. Manufacturing and Service Operations Management 22: 113-22. [CrossRef]

Pan, Shan L., and Sixuan Zhang. 2020. From fighting COVID-19 pandemic to tackling sustainable development goals: An opportunity for responsible information systems research. International Journal of Information Management 55: 102196. [CrossRef]

Pandey, Neena, and Abhipsa Pal. 2020. Impact of digital surge during Covid-19 pandemic: A viewpoint on research and practice. International Journal of Information Management 55: 102171. [CrossRef]

Priyono, Anjar, Abdul Moin, and Vera Nur Aini Oktaviani Putri. 2020. Identifying digital transformation paths in the business model of SMEs during the COVID-19 pandemic. Journal of Open Innovation: Technology, Market, and Complexity 6: 104. [CrossRef]

Rao, Sriganesh K., and Ramjee Prasad. 2018. Impact of 5G technologies on industry 4.0. Wireless Personal Communications 100: 145-59. [CrossRef]

Roostaie, Samira, Nawari Nawari, and Charles Kibert. 2019. Sustainability and resilience: A review of definitions, relationships, and their integration into a combined building assessment framework. Building and Environment 154: 132-44. [CrossRef]

Ruiz-Martin, Cristina, Adolfo López-Paredes, and Gabriel Wainer. 2018. What we know and do not know about organizational resilience. International Journal of Production Management and Engineering 6: 11-28. [CrossRef]

Sachs, Jeffrey D., Guido Schmidt-Traub, Mariana Mazzucato, Dirk Messner, Nebojsa Nakicenovic, and Johan Rockström. 2019. Six transformations to achieve the sustainable development goals. Nature Sustainability 2: 805-14. [CrossRef]

Sanchis, R., L. Canetta, and R. Poler. 2020. A conceptual reference framework for enterprise resilience enhancement. Sustainability 12: 1464. [CrossRef]

Sarkis, Joseph. 2021. Supply chain sustainability: Learning from the COVID-19 pandemic. International Journal of Operations and Production Management 41: 63-73. [CrossRef]

Savka, Olga. 2021. Influence of the humanitarian environment on improving the quality of training of specialists in a technical university. Russian Technological Journal 9: 92-102. [CrossRef]

Schot, Johan, and W. Edward Steinmueller. 2018. Three frames for innovation policy: R\&D, systems of innovation and transformative change. Research Policy 47: 1554-67. [CrossRef]

Shahzad, Mohsin, Ying Qu, Abaid Ullah Zafar, and Andrea Appolloni. 2021. Does the interaction between the knowledge management process and sustainable development practices boost corporate green innovation? Business Strategy and the Environment 30: 4206-22 [CrossRef]

Shaked, Haim, and Chen Schechter. 2020. Systems thinking leadership: New explorations for school improvement. Management in Education 34: 107-14. [CrossRef] 
Sharma, Gagan Deep, Asha Thomas, and Justin Paul. 2021. Reviving tourism industry post-COVID-19: A resilience-based framework. Tourism Management Perspectives 37: 100786. [CrossRef] [PubMed]

Shaw, Rajib, Yong-kyun Kim, and Jinling Hua. 2020. Governance, technology and citizen behavior in pandemic: Lessons from COVID-19 in East Asia. Progress in Disaster Science 6: 100090. [CrossRef]

Sheth, Jagdish. 2020. Impact of Covid-19 on consumer behavior: Will the old habits return or die? Journal of Business Research 117: 280-83. [CrossRef] [PubMed]

Sigala, Marianna. 2020. Tourism and COVID-19: Impacts and implications for advancing and resetting industry and research. Journal of Business Research 117: 312-21. [CrossRef]

Stahl, Günter K., Chris J. Brewster, David G. Collings, and Aida Hajro. 2020. Enhancing the role of human resource management in corporate sustainability and social responsibility: A multi-stakeholder, multidimensional approach to HRM. Human Resource Management Review 30: 100708. [CrossRef]

Stevenson, Joanne R., Charlotte Brown, Erica Seville, and John Vargo. 2018. Business recovery: An assessment framework. Disasters 42: 519-40. [CrossRef]

Strielkowski, Wadim, Irina Firsova, Inna Lukashenko, Jurgita Raudeliūnienė, and Manuela Tvaronavičienė. 2021. Effective management of energy consumption during the COVID-19 pandemic: The role of ICT solutions. Energies 14: 893. [CrossRef]

Suriyankietkaew, Suparak. 2019. Sustainable leadership and entrepreneurship for corporate sustainability in small enterprises: An empirical analysis. World Review of Entrepreneurship, Management and Sustainable Development 15: 256-75. [CrossRef]

Ulak, Nimesh. 2020. COVID-19 Pandemic and its impact on tourism industry in Nepal. Journal of Tourism and Adventure 3: 50-75. [CrossRef]

United Nations. 2021. UN E-Government Survey 2020. Available online: https://publicadministration.un.org/egovkb/en-us/ Reports/UN-E-Government-Survey-2020 (accessed on 20 January 2022).

Verick, Sher, Dorothea Schmid-Klau, and Sangheon Lee. 2021. Is this time "really" different? How the impact of the COVID-19 crisis on labour markets contrasts to the global financial crisis of 2008-9. International Labour Review. accepted article. [CrossRef] [PubMed]

Wang, Guomeng, Huiming Huang, and Quanquan Zheng. 2015. Effect of Chinese employees' emotional creativity on their innovative performance. Social Behavior and Personality: An International Journal 43: 1147-60. [CrossRef]

Watts, Geoff. 2020. COVID-19 and the digital divide in the UK. The Lancet Digital Health 2: e395-96. [CrossRef]

Westerman, James W., Lubna Nafees, and Jennifer Westerman. 2021. Cultivating Support for the Sustainable Development Goals, Green Strategy and Human Resource Management Practices in Future Business Leaders: The Role of Individual Differences and Academic Training. Sustainability 13: 6569. [CrossRef]

Wilson, Mel. 2003. Corporate sustainability: What is it and where does it come from. Ivey Business Journal 67: 1-5.

Wilson, Suze. 2020. Pandemic leadership: Lessons from New Zealand's approach to COVID-19. Leadership 16: 279-93. [CrossRef]

Xu, Zhitao, Adel Elomri, Laoucine Kerbache, and Abdelfatteh El Omri. 2020. Impacts of COVID-19 on global supply chains: Facts and perspectives. IEEE Engineering Management Review 48: 153-66. [CrossRef]

Yadav, Hitesha, Arpan Kumar Kar, and Smita Kashiramka. 2021. How does entrepreneurial orientation and SDG orientation of CEOs evolve before and during a pandemic. Journal of Enterprise Information Management. ahead-of-print. [CrossRef]

Yong, Jing Yi, Mohd-Yusoff Yusliza, Thurasamy Ramayah, Charbel Jose Chiappetta Jabbour, Simone Sehnem, and Venkatesh Mani. 2020. Pathways towards sustainability in manufacturing organizations: Empirical evidence on the role of green human resource management. Business Strategy and the Environment 29: 212-28. [CrossRef]

Yu, Krista Danielle S., Kathleen B. Aviso, Joost R. Santos, and Raymond R. Tan. 2020. The economic impact of lockdowns: A persistent inoperability input-output approach. Economies 8: 109. [CrossRef]

Zgórska, Barbara, Dorota Kamrowska-Załuska, and Piotr Lorens. 2021. Can the Pandemic Be a Catalyst of Spatial Changes Leading Towards the Smart City? Urban Planning 6: 216-27. [CrossRef]

Zhong, Yifan, Yameng Li, Jian Ding, and Yiyi Liao. 2021. Risk Management: Exploring Emerging Human Resource Issues during the COVID-19 Pandemic. Journal of Risk and Financial Management 14: 228. [CrossRef] 